\title{
Pasture BMP Effectiveness Using an HRU-based Subarea Approach in SWAT
}

\author{
Aleksey Y. Sheshukov* ${ }^{* \dagger}$, Kyle R. Douglas-Mankin ${ }^{\dagger}$, Sumathy Sinnathamby ${ }^{\dagger}$, Prasad \\ Daggupati $^{\dagger}$ \\ ${ }^{\dagger}$ Biological and Agricultural Engineering, Kansas State University, Manhattan, KS 66506, USA
}

\begin{abstract}
Many conservation programs have been established to motivate producers to adopt best management practices (BMP) to minimize pasture runoff and nutrient loads, but a process is needed to assess BMP effectiveness to help target implementation efforts. A study was conducted to develop and demonstrate a method to evaluate water-quality impacts and the effectiveness of two widely used BMPs on a livestock pasture: off-stream watering site and stream fencing. The Soil and Water Assessment Tool (SWAT) model was built for the Pottawatomie Creek Watershed in eastern Kansas, independently calibrated at the watershed outlet for streamflow and at a pasture site for nutrients and sediment runoff, and also employed to simulate pollutant loads in a synthetic pasture. The pasture was divided into several subareas including stream, riparian zone, and two grazing zones. Five scenarios applied to both a synthetic pasture and a whole watershed were simulated to assess various combinations of widely used pasture BMPs: (1) baseline conditions with an open stream access, (2) an off-stream watering site installed in individual subareas in the pasture, and (3) stream or riparian zone fencing with an off-stream watering site. Results indicated that pollutant loads increase with increasing stocking rates whereas off-stream watering site and/or stream fencing reduce time cattle spend in the stream and nutrient loads. These two BMPs lowered organic P and N loads by more than $59 \%$ and nitrate loads by $19 \%$, but TSS and sediment-attached P loads remained practically unchanged. An effectiveness index (EI) quantified impacts from the various combinations of off-stream watering sites and fencing in all scenarios. Stream bank contribution to pollutant loads was not accounted in the methodology due to limitations of the SWAT model, but can be incorporated in the approach if an amount of bank soil loss is known for various stocking rates. The proposed methodology provides an adaptable framework for pasture BMP assessment and was utilized to represent a consistent, defensible process to quantify the effectiveness of BMP proposals in a BMP auction in eastern Kansas.
\end{abstract}

Keywords: Best Management Practices; Grazing management; Hydrologic Response Unit; Pasture; Livestock; SWAT

*Corresponding author Aleksey Y. Sheshukov (Email: ashesh@ksu.edu, Tel: +1 785532 5418, Fax: +1 785532 5825), Kyle R. Douglas-Mankin (Email: krdmankin@gmail.com), Sumathy Sinnathamby (Email: sumathys@ksu.edu), Prasad Daggupati (Email: pdaggupati@tamu.edu) 
31 1. Introduction

Over 191 million hectares, or more than 50\% of pastureland, rangeland, and woodland in the United States, are used for livestock grazing activities (USDA-NASS, 2008). These activities may contribute to impairment of water bodies by polluting nutrients, bacteria, and sediment (Haan et al., 2006; U.S. EPA, 2004). Use of rivers and streams as a primary source of water for livestock leads to increased grazing time in or near the stream, resulting in direct deposition of animal waste into the stream accompanied by bank erosion at stream access and crossing locations. Properly implemented best management practices (BMP) can significantly reduce the pollutant footprint of grazing lands. One goal for grazing management and sediment-control BMPs is to protect sensitive areas of the pasture, such as streams, riparian zones, and ponds, by restricting livestock access.

Common BMPs that support stream protection consist of an alternative off-stream water source, a riparian buffer, and exclusion fencing (U.S. EPA, 2004). The alternative water source attracts livestock away from primary water bodies, such as streams, ponds and lakes, whereas the fencing completely eliminates access to streams and prevents direct animal waste contribution as well as mechanical disturbance to banks that may cause excessive soil erosion. Fencing requires that an alternative off-stream water source exists. Riparian areas along a stream function similar to vegetative filters at the edge of agricultural fields by filtering runoff and trapping pollutants before they reach the stream (Mankin et al., 2007).

Many studies (Sheffield et al., 1997; Line et al., 2000; Agouridis et al., 2005) observed substantial decrease in sediment losses after stream fencing. For example, Owens et al. (1996) observed that after stream and riparian buffer were fenced, annual TSS concentrations decreased by $50 \%$ over the following five years. Line et al. (2000) and Sheffield et al. (1997) reported TSS concentration reductions of more 
mineralized components of $\mathrm{N}$ and $\mathrm{P}$ loads are attached to and transported with sediment; therefore, $\mathrm{N}$ and

57 P reductions correlate with reductions in sediment concentrations.

58 A few field studies were conducted to assess stream water-quality improvement due to restriction of 59 stream access for cattle on grazing fields (Miner et al., 1992; Owens et al., 1996; Sheffield et al., 1997;

60 Line et al., 2000; Agouridis et al., 2005). Miner et al. (1992) and Sheffield et al. (1997) observed above $6190 \%$ reduction of time cattle spent in stream if the off-stream watering site was introduced. Clawson 62 (1993) reported $81 \%$ time reduction and concluded that cattle preferred to drink $75 \%$ of the time from 63 trough than from stream. McInnis and McIver (2001) found small reductions in near-stream hoof traffic 64 from off-stream water and salt, but these reductions yielded significant reductions in development of 65 unstable stream banks. Daily use of a stream with no off-site water source in the pasture varied from 66 relatively short periods (4.7 min. by Clawson, 1993; $6.7 \mathrm{~min}$. by Sheffield et al., 1997; and $14.5 \mathrm{~min}$. by 67 Miner et al., 1992) to prolonged periods of above $90 \mathrm{~min}$. (Pandey et al., 2009). Such variation in daily 68 stream use leads to differences in water-quality impact and improvements if the stream is fenced or 69 restricted. Agouridis et al. (2005) monitored cattle spatial variability within two pasture fields, and 70 statistically analyzed cattle positions over a 1.5-year period, and concluded a positive correlation between 71 the stream bank erosion and stocking density at 50 stream cross-sectional areas.

72 Preferential grazing patterns within a pasture cause concentrated points of manure depositions, which 73 affect native levels of soil organic nutrient components. Spatial variation of soil properties also can be due 74 to geological factors or can be imposed by soil management practices. Sauer and Meek (2003) studied 75 spatial variation of soil $\mathrm{P}$ in two pasture fields. The impact of morphological factors was found to be 76 secondary to management factors. They also found that the history of grazing activity in the pasture 77 affects nutrient content in soil, thus affecting pollutant runoff. Areas of higher P occur mostly near gates, 78 roads, stream, and watering sites (Sauer and Meek, 2003; Penn et al., 2009). Areas of high slope have 79 greater potential to generate surface runoff, accompanying soil loss, and sediment-attached $\mathrm{P}$ than areas 
with low slope (Haan et al., 2006). Representation of these preferential grazing patterns and morphological features are needed in models to better assess the environmental impact of grazing BMPs.

Phosphorous loss in runoff is considered an important indicator of pasture environmental quality, and several models were developed to assess impacts of grazing BMPs on soil health (USDA-NRCS, 1994; Wade et al., 1998; White et al., 2009; Nelson and Shober, 2012). The Phosphorous Index (PI) model is a qualitative tool to assess various land forms for potential risk of P runoff to water bodies (USDA-NRCS, 1994; Nelson and Shober, 2012). The tool computes $\mathrm{P}$ index rating for a pasture area as a sum of eight $\mathrm{P}$ loss factors and weighting coefficients. P loss factors range from low to high and split into categories related to soil erosion, runoff, soil test $\mathrm{P}, \mathrm{P}$ fertilizer application rate and method, and organic $\mathrm{P}$ source application rate and method (Lemunyon and Gilbert, 1993). The $\mathrm{P}$ index rating result from application of weighted coefficients to interpret the site vulnerability ratings. The tool mainly relies on general pasture information and does not use spatial characteristics or management operations. The Grazing Potential Index model (GPI; Wade et al., 1998) uses land characteristics, pasture proximity to the stream, and forage availability to assess environmental potential. The model statistically distributes cattle within the pasture based on geographical features such as the nearest permanent water source(s), land slopes, and forage availability, and assigns a GPI score to different areas within the watershed. The areas with higher GPI scores are expected to be favored by livestock. Although this model produces spatial representations of grazing patterns, it does not quantitatively calculate nutrient loads to the stream. The Pasture Phosphorous Management (PPM) calculator (White et al., 2009) is a quantitative P assessment tool that uses the Soil and Water Assessment Tool (SWAT) model to pre-process P loads for individual Hydrologic Response Units (HRU) and lets a user select the corresponding representation of the grazing area. Grazing management operations, stocking rates, and fertilizer applications are inputs to the model on a monthly basis. The PPM Calculator presents a quantitative way to evaluate the P runoff from a pasture; however, it does not account for unique land characteristics at different parts of the pasture, 


\subsection{Pasture design}

Pasture fields are lands of low-growing vegetation (grasses, shrubs, plants, etc.) utilized for animal grazing. Pasture fields differ in size, topography, soil characteristics, forage type, and grazing management and normally contain an access point to water. A typical water source can be a stream flowing through pasture or an alternative off-stream watering site (a pond or an artificially build trough) (Ohlenbusch and Harner, 2003). A pond or any alternative source of water that is hydrologically disconnected from a stream provides an opportunity to capture majority of animal waste that otherwise would have been excreted directly into the stream. A vegetative buffer or riparian area is a native or created buffer adjacent to a stream to reduce pollutant transport to the streams (U.S. EPA, 2004).

In this study, we defined a pasture to consist of three parts: a grazing area, a riparian area, and a stream. 
the stream and by its land cover characteristics cannot be interpreted as riparian buffer. If an alternative

130 watering site is present, it is assumed to be located within the grazing area and have no direct outflow to 131 the stream. Both the grazing area and the riparian buffer can be divided further into subareas according to 132 individual land characteristics, such as topography, soil type, and land cover, and management operations. 133 Within each subarea, the characteristics are assumed to be uniform.

\section{2.2. Stocking rate}

135 Variability in grazing distribution can be accounted by using individual stocking rates (SR) for each 136 subarea. Generally, the average SR for an entire pasture area is expressed as the number of animal units 137 (AU; $1 A U=1,000 \mathrm{~kg}$ of animal weight) allocated per unit of land area $A$ (1 ha) in one day (Ohlenbusch 138 and Watson, 1994; Redfearn and Bidwell, 1997). For an individual subarea $i$ in the pasture, the local 139 stocking rate $\left(S R_{i}\right)$ relates to a daily fraction of the grazing time by:

141 while average stocking rate $S R_{\mathrm{AVG}}$ for pasture with $N$ subareas can be expressed using an area-weighted 142 approach as

$$
S R_{\mathrm{AVG}}=\sum_{i=1}^{N}\left(S R_{i} A_{i}\right) / \sum_{i=1}^{N} A_{i}
$$

\subsection{SWAT model}

The Soil and Water Assessment Tool (SWAT) (Arnold et al., 1998; Neitsch et al., 2004, 2005) is a widely used watershed model (Gassman et al., 2007; Douglas-Mankin et al., 2010) that was utilized in this study to simulate hydrological and water-quality processes at the field (or pasture) and watershed scales. SWAT is a complex continuous simulation model that incorporates a set of both physically and empirically based equations within multiple modules that proceed either independently of each other or use outputs of one module as inputs for another module within one time-step. Both pasture-scale and watershed-scale modules are implemented in SWAT. Based on topography and using the Geographic 
Information System (GIS) module within ArcGIS (ESRI, 2011) for pre-processing geospatial layers, SWAT delineates a watershed into subwatersheds that are further subdivided into areas of homogeneous soil type, land cover, and slope range, called Hydrologic Response Units (HRU). HRUs are used to simulate all processes that occur at the pasture scale, including hydrologic budget, plant growth, erosion, and nutrient cycles. The amount of water, nutrients, and sediment flowing from the HRUs into streams are accounted at the daily time scale and collected as HRU outputs.

Applying the HRU framework to pasture area, subareas within the pasture can be represented by individual HRUs. For example, pasture (identified in SWAT as PAST) and rangeland (RNGE) land cover represent grazing subareas, and deciduous forest (FRSD) and range-brush mix (RNGB) represent riparian subareas. We note that stream subarea was not simulated in SWAT.

SWAT requires a large number of input parameters that are divided into the groups of watershed-scale and pasture-scale parameters. Many watershed-scale parameters, such as land cover, soil, geographical features, and groundwater parameters, are either loaded directly as attributes of geospatial layers or calculated from them. Twelve pasture-scale parameters that relate to land management and practices in the pasture are presented in Table 1 and applied to grazing and riparian HRUs. The amount of minimum dry above ground biomass at which grazing is permitted, pasture initial conditions, operation schedule, and daily amounts of biomass consumed and trampled are input into the SWAT project database based on the SR and knowledge of animal behavior in the pasture.

Loadings of six specified pollutants (soluble P [defined in SWAT by SOLP], organic P [ORGP], sediment-attached $\mathrm{P}$ [SEDP], organic $\mathrm{N}[\mathrm{ORGN}]$, nitrate $\left[\mathrm{NO}_{3}-\mathrm{N}\right]$, and suspended solids [TSS]) for each subarea in the pasture besides the stream subarea are collected from the unit-area HRU outputs $(\omega)$. For stream subareas an approach is used based on fractions of nutrients in animal waste that are directly applied to the stream load:

$$
\omega_{\text {stream }}=\chi \cdot m \cdot S R_{\text {stream }}
$$


where $m=8.5 \mathrm{~kg}$, and $\chi$ is percent of the selected nutrient constituent in dry solid manure, $1.0 \%$ for $\mathrm{NO}_{3}$ N, 3.0\% for ORGN, $0.4 \%$ for SOLP, $0.7 \%$ for ORGP, and $0 \%$ for SEDP and TSS according to the ASAE standards (ASAE, 1999) and SWAT database (Neitsh et al., 2005). Total load $W_{\text {pasture }}$ of each pollutant for the entire pasture can be calculated as:

$$
W_{\text {pasture }}=\omega_{\text {stream }} A_{\text {stream }}+\omega_{2} A_{2}+\omega_{3} A_{3}+\cdots+\omega_{N} A_{N}
$$

\subsection{BMP effectiveness}

Various pasture BMPs are designed to improve water-quality conditions in the pasture; reduce $\mathrm{P}, \mathrm{N}$, and TSS loads; and optimize grazing management. Among many pasture BMPs such as cross fencing, stream fencing, rotational grazing, and alternative watering sites, only a few can be represented within current continuous water-quality models. In this study, a procedure was developed to simulate two pasture BMPs, both related to reducing stream access: creating off-stream watering sites and fencing streams and/or buffers (Ohlenbusch and Harner, 2003). By establishing an off-stream watering site in upland subareas of the pasture, it increases the fraction of daily time that cattle graze there, which increases SR in the subarea of the alternative watering site and reduces SR in the area near the stream. If fencing is applied, the fenced areas (stream or buffer) are considered inaccessible for grazing, and SR in these areas is set to zero.

Two types of modeling scenarios were introduced in this study. Grazing scenario in a pasture with no implemented BMPs will be called the baseline scenario, while a pasture with implemented fencing or offstream watering site will be called a BMP scenario. A water-quality impact of implemented BMPs can be calculated by comparing the pollutant loads in baseline and BMP scenarios using either an effectiveness index (EI, \%) for a single pollutant or the cumulative effectiveness index (CEI, \%) in the case of $M$ multiple pollutants:

$$
E I_{j}=\frac{W_{j}^{\text {baseline }}-W_{j}^{B M P}}{W_{j}^{\text {baseline }}} 100 \%, \quad C E I=\sum_{j=1}^{M}\left(\phi_{j} E I_{j}\right)
$$


where $j$ represents a pollutant and $\phi_{j}$ are weighting coefficients according to pollutant ranking table. In this 200 study, the six pollutants $(M=6)$ specified above as outputs of the SWAT model were considered of equal 201 importance, thus, $\phi_{j}=0.167$.

\section{3. Study area}

\subsection{Model setup}

The pasture BMP effectiveness method was tested in the $897-\mathrm{km}^{2}$ Pottawatomie Creek Watershed in eastern Kansas (Fig. 1). The SWAT ver. 2005 model was built for the watershed with the main outlet set at the USGS gauging station 06914100 on Pottawatomie Creek near the town of Scipio, Kansas (USGS, 2009; Fig. 1b). Based on geospatial datasets of 10-m Digital Elevation Model, 30-m NLCD land cover, and SSURGO soil database (Homer et al., 2007; USDA-NRCS, 2005; Sheshukov et al., 2011), the watershed was delineated into seven subwatersheds and 6066 HRUs. Watershed land uses were primarily grazing land (46\%) and cropland (30\%), and soil was predominantly (80\%) silt loam of high runoff potential (hydrologic soil group type D). According to land-ownership parcels in eastern Kansas, the watershed is comprised of 403 sections of land (260 ha, 640 acres) with grazing land occupying on average 163 ha (from 13 ha to 250 ha) of each section (Fig. 1b). Following practices used in eastern Kansas, continuous corn with a mix of conventional and no-till practices were applied to all cropland HRUs, while pasture HRUs had tall fescue grass growing all year and grazed with an average SR of 0.8 AU/ha.

Due to availability of edge-of-field sampling data, a 3.5 hectare dairy pasture field in subwatershed 7 composed of tall fescue grass in low slope (80\%) and high slope (20\%) areas was identified for pasture scale analysis. Three HRUs represented the pasture and 200 dairy cattle were grazed throughout the year. Specific grazing management operation parameters used in the model are provided in Table 1. 
Timeseries of daily temperature and precipitation from 1995 to 2005 from two NCDC cooperative weather stations 143008 and 143441 (NCDC, 2009) were collected for weather input in subwatersheds 1 to 6 . For subwatershed 7 , daily records from the onsite weather station at the dairy pasture were used instead. The model was run for seven years (1999-2005), with the first 2 years used for model spin-off.

\subsection{Model calibration}

Two types of calibration procedures were conducted to ensure acceptable performance of the SWAT model at both the watershed and pasture scales. First, the simulated daily streamflow was compared with data from the gaging station at the watershed outlet. The following statistical parameters were used for calibration (Moriasi et al., 2007): the Nash-Sutcliffe efficiency coefficient (NSE; Nash and Sutcliffe, 1970), the coefficient of determination $\left(\mathrm{R}^{2}\right)$, the root mean square error to standard deviation ratio (RSR), and the percent bias (PBIAS). Seven model parameters shown in Table 2 were adjusted during hydrologic calibration process. The final statistics presented in Table 3 was rated from very good (NSE $>0.75$; RSR $\leq 0.50)$ to good $( \pm 10 \% \leq$ PBIAS $< \pm 15 \%)$ according to Moriasi et al. (2007). Second, water samples from 2001 to 2005 were used to calibrate the model for sediment and nutrient runoff at the pasture scale (Mankin et al., 2007; Fig. 1c). An automated sampler (Model 6700; Onset, 2008) was installed at the edge of the pasture field, and a total of 22 flow-weighted water samples were collected on a bi-weekly schedule from multi-day runoff events. Samples were analyzed for total phosphorous $(\mathrm{P})$, nitrate $\left(\mathrm{NO}_{3}-\mathrm{N}\right)$, and suspended solids (TSS) using methods described in APHA (1998). The observed concentrations were compared with the SWAT-simulated concentrations of the same pollutants aggregated for each sampling period using area-weighted concentrations from three HRUs comprising the pasture field. Five model parameters (Table 2) were adjusted during the calibration process, which resulted in satisfactory model performance for TSS (PBIAS < $\pm 55 \%)$ and very good performance for total $\mathrm{P}$ and $\mathrm{NO}_{3}-\mathrm{N}(\mathrm{PBIAS}<$ $\pm 25 \%$ ) (Table 3; Moriasi et al., 2007). In addition, mean and ranges of observed and calibrated streamflow and pollutant concentrations were compared in Table 3 and showed adequate model 
performance. Based on the statistics of two calibration procedures, the model was deemed acceptable for simulation of pasture BMP effectiveness.

\subsection{Synthetic pasture scenarios}

After the SWAT model was built and calibrated at the watershed and pasture scales, an example synthetic pasture was configured to evaluate effectiveness of pasture BMPs. The distribution of pasture and forest HRUs and a stream length in the watershed were used as basis to design a synthetic pasture. Based on total area of all pastureland as 51,300 ha, total length of streams crossing through pastureland as $789 \mathrm{~km}$, and assuming typical 10-meter wide floodplain and 15-meter wide riparian zone on each side of the stream, stream area and riparian buffer were found to occupy $1.6 \%$ and $4.5 \%$ of total pastureland in the watershed, respectively. These percentages were used to define subareas within the synthetic pasture. A synthetic pasture was selected to represent a quarter-section (65 ha, 160 acres) of land-ownership parcel and contained an in-stream area (1 hectare; defined as S), a riparian zone (3 hectares; $\mathrm{R})$, and grazing area (61 hectares). To account for land variability, the grazing area was additionally divided into two grazing subareas G1 and G2 of the same soil type.

An average slope of all pastureland was $1.2 \%$, with riparian areas sloped at $0.4 \%$. The subarea G1 was selected to represent low slope topography, whereas G2 covered high-slope area. Areas of G1 and G2 varied for different scenarios and SWAT runs. Three specific HRUs from the SWAT model were selected to represent pasture subareas; two HRUs identified with PAST landuse represented areas G1 and G2, and one HRU with RNGE landuse represented area R. Two HRUs selected for G1 and R had slopes of $0.4 \%$ for all runs. The slope of the second pasture HRU for G2 was appropriately adjusted to satisfy the average pasture slope of $1.2 \%$, and SWAT model was reran for each new scenario.

Cattle stocking rate of $0.8 \mathrm{AU} / \mathrm{ha} /$ day were used for uniform grazing within the whole synthetic pasture without considering preferential grazing patterns. Daily amount of time that cattle spent in each subarea was strictly based on the area of grazing and riparian subareas, while for not-fenced stream subarea it was 
assumed at 14 minutes (1\% of each day). This selected duration of stream time was similar to Miner et al. (1992), however, other durations of up to 140 minutes (10\%) were also tested in simulations.

The baseline and four BMP scenarios were simulated for the synthetic pasture. In the baseline scenario, cattle spent 14 minutes ( $1 \%$ of 24 hours) in stream subarea, 67 minutes in subarea $B$, and 1,359 minutes in subareas G1 and G2. The first two BMP scenarios, W1N and W2N, simulated BMPs with offstream watering site installed in grazing areas G1 and G2, respectively, and no stream fencing. Because of the presence of off-site watering site, the stream time was assumed to be reduced by $90 \%$ as similar to Miner et al. (1992) and Sheffield et al. (1997). Other reductions in stream time (from $50 \%$ to $100 \%$ ) were also tested and discussed in section 4. The final two BMP scenarios, W1F and W2F, represented a combination of an off-stream watering site in either G1 or G2 complemented by stream fencing. In these two scenarios cattle has no access to stream and spend all daily time grazing in subareas G1 and G2.

\section{Results}

The SWAT model for the Pottawatomie Creek watershed, calibrated at watershed and pasture scales, was run many times with stocking rates varying from 0 to $3 \mathrm{AU} / \mathrm{ha}$ applied to all grazing (RNGE, HAY) and forested (FRSD, RNGB) HRUs. For each run, annual average loads of six pollutants (TSS, SEDP, ORGP, SOLP, ORGN, $\mathrm{NO}_{3}-\mathrm{N}$ ) were collected in all HRUs, aggregated to represent the pasture according to Eq. (4), and used to calculate pasture BMP effectiveness indices EI and CEI with Eq. (5). The results were applied to simulate baseline and four BMP scenarios for the following two pasture sets: (1) a single synthetic pasture comprised of four subareas and (2) all 403 pastures in the entire Pottawatomie Creek watershed. Synthetic pasture scenarios and results are presented in details while the statistics of the BMP applications to the entire watershed is summarized and discussed.

Annual average loads for the synthetic pasture are presented in Fig. 2a for the baseline scenario, while the loads for four BMP scenarios are shown in Fig. 2b as changes from the baseline. The subareas G1, G2, R, and $\mathrm{S}$ were set as default at 50 ha, 11 ha, 3 ha and 1 ha, respectively. In addition, range bars in Fig. 
2a represent ranges of loads for grazing subarea G1 varying from 0 to 61 ha. Pasture pollutants related to sediment runoff show the largest variation in loads with the change in area of G1, with the loads of TSS and SEDP increasing 14 times from pasture configuration with 100\% G1 and no G2 area to the configuration with no G1 and 100\% G2 area (Fig. 2a). The high-slope subarea G2 produces 20 times more sediment runoff than G1, thus contributing more to TSS and SEDP loads with a decrease of G1. Loads of other pollutants (ORGP, SOLP, ORGN, $\mathrm{NO}_{3}-\mathrm{N}$ ) increased only by about $5 \%$ with decrease of G1 indicating that they rely more on either phosphorous and nitrogen concentrations stored in the soil or applied in a form of manure to the soil or directly in the stream. For the default case of G1 area of 50 ha, the stream contribution to total pasture loads was $66 \%$ for ORGP, $94 \%$ for ORGN, and $21 \%$ for $\mathrm{NO}_{3}-\mathrm{N}$. For SOLP, the major contributor was the grazing subarea G1 at $81 \%$. The conducted additional tests with different sizes of the riparian subarea revealed the decrease of total pasture TSS and SEDP loads with an increase of riparian buffer.

Benefits of the reduction in stream time were apparent when examining net nutrient loads from BMP scenarios when compared to their respective baseline scenarios (Fig. 2b). The reduction in stream time for scenarios $\mathrm{W} 1 \mathrm{~N}$ and $\mathrm{W} 2 \mathrm{~N}$ relative to the baseline scenario reduced the pollutant stream contribution by $90 \%$ and reduced organic nutrient loads by $85 \%$ for ORGN, $59 \%$ for ORGP, and $19 \%$ for $\mathrm{NO}_{3}-\mathrm{N}$, whereas SOLP, TSS, and SEDP loads remained practically unaffected. Fencing a stream in scenarios $\mathrm{W} 1 \mathrm{~F}$ and $\mathrm{W} 2 \mathrm{~F}$ completely eliminated access to stream, thus increased stocking rates and manure deposition in grazing subareas. However, the fencing led to only an incremental decrease in pollutant loads in contrast with a substantial reduction caused by the off-stream watering site.

The impact of pasture topography on BMP effectiveness is presented in Fig. 3 for four BMP scenarios by varying the area of G1 from $0 \%$ to $100 \%$ (61 ha) coverage. The CEI increased with the increase of G1 area for all BMPs reaching its maximum value when G1 area occupies $100 \%$ of the grazing land. Similar to the analysis of pollutant loads presented in Fig. 2, the presence of off-stream watering site in scenarios $\mathrm{W} 1 \mathrm{~N}$ and W2N had a much stronger impact on BMP effectiveness (CEI ranged from $19.7 \%$ to $31 \%$ ) and 
pollutant load reductions than impacts caused by additional stream fencing. Two fencing scenarios (W1F, W2F) consistently produced higher CEIs than a non-fencing scenario (W1N, W2N) for any percentage of G1 area, however, the difference in CEI was only $1.8 \%$ for zero G1 subarea, and increased to $3.4 \%$ for G1 subarea occupying $100 \%$. A placement of the watering site in a low-slope area G1 was slightly more efficient than placing it in the high-slope area G2, with CEI increasing with the increase of contribution of G1 in grazing area. This was also confirmed by assessing BMPs in all pastures in the watershed; average CEI reduced from $38 \%$ for low-slope $(0.01 \%)$ pasture to $31 \%$ for high-slope $(6 \%)$ pasture.

Major factors influencing load calculations were the daily grazing times in pasture subareas, especially in the stream. The stream time was assumed in the synthetic pasture configuration as $1 \%$ of daily time or 14 minutes for the baseline scenario; it was additionally reduced by $90 \%$ (1.4 minutes) for scenarios W1N and $\mathrm{W} 2 \mathrm{~N}$ with off-stream watering site, or completely eliminated ( 0 minutes) for scenarios $\mathrm{W} 1 \mathrm{~F}$ and W2F with stream fencing. The pre-BMP baseline stream time and its reduction as a result of BMP scenarios can be considered site specific and may vary seasonally. The sensitivity of BMP efficiency to the variability in stream time was evaluated in Fig. 4 by plotting CEI as a function of the reduction in stream grazing time in $\mathrm{W} 1 \mathrm{~N}$ scenario. The daily stream grazing time varied from 7 minutes (curve 1) to 120 minutes (curve 4) for synthetic pasture scenarios. The CEI gradually increased as the stream time increased, which reflects the fact that overall pollutant reduction was responsive to implementation of the off-stream watering site. However, there were diminishing returns for each increment of stream time increase; the relative magnitude of reductions decreased as stream time increased. In addition, CEI increased for greater reductions in stream time for any given pre-BMP stream grazing time. A 100\% reduction in time represents the case of completely halting the stream access for grazing, which is similar to stream fencing in W1F scenario. The increase in CEI that results from greater reductions in stream time confirms intuition. However, also evident in Fig. 4 is that the rate of increase in CEI per unit of reduction in time increases slightly as pre-BMP stream time increases. For example, a shift from $50 \%$ to $100 \%$ stream time reduction led to a $13 \% \mathrm{CEI}$ increase for curve 1 ( $7 \mathrm{~min}$ ) compared to a $18 \% \mathrm{CEI}$ 
increase for curve 3 (30 min). Thus, settings in which cattle initially (pre-BMP) spend more time in the stream may show a greater response per unit of reduction in stream time resulting from a given BMP.

Similar behavior was observed while evaluating all 403 pastures in the watershed. The range of CEI for W1N scenario with 14-minute stream time is presented in Fig. 4 as a shaded area, while the mean trend is shown by the dashed line. Comparing with curve 2 for the synthetic pasture, the watershed overall exhibited better response and from 5 to $10 \%$ higher BMP effectiveness to off-stream watering site installation.

\title{
5. Discussion
}

\begin{abstract}
Studying the baseline scenario revealed that accounting for stream subarea in configuring a pasture can increase nutrient contribution from pasture and substantially improve estimation of BMP efficiency. Localized high-slope grazing areas in a pasture may affect hillslope hydrology, increase soil erosion and transported pollutants.
\end{abstract}

The results presented in section 4 demonstrated that an off-stream watering site can positively affect concentrations of animal waste in the stream by attracting livestock to spend longer times away from the stream. Stream fencing provided additional reduction in pollutant loads; although, the increase in effectiveness was marginal compared to the impact of an off-stream watering site. These results correspond with the findings of Sheffield et al. (1997), Line et al. (2000), and Agouridis et al. (2005). For $\mathrm{SR}_{\mathrm{AVE}}=0.8 \mathrm{AU} / \mathrm{ha}$, keeping livestock away from the stream reduced organic components of $\mathrm{P}$ and $\mathrm{N}$ by $85 \%$ and $59 \%$, nitrates by $19 \%$, however, TSS and SEDP remained almost unchanged which contradicted the other experimental studies (Sheffield et al., 1997). The disparity between the results mainly occurred due to not accounting for stream bank erosion in SWAT, a potentially significant contributor to stream TSS. A reduction in grazing time near a stream should decrease trampling and other deteriorating effects on banks that were found important by Sheffield et al. (1997) and Aguoridis et al. (2005) but not explicitly included in the SWAT model. We predict that accounting for bank erosion by incorporating 
367 stream bank soil loss components in Eq. (4) would increase the BMP effectiveness of both fencing and 368 off-stream watering site practices. Regardless of this shortcoming, the methodology presented in this 369 paper provides a viable tool to assist expert management teams in evaluating the effectiveness of an off370 stream watering site and stream fencing. As an example, this approach was used in making management 371 decisions to award producers for BMP implementation on producer pasture fields as part of the livestock 372 BMP auction (U.S. EPA, 2009). The awarded installation of the off-stream watering site not only 373 produced high effectiveness index but also appeared to be the most cost-efficient compared to other BMP 374 proposals. In contrast, the stream fencing and riparian buffer fencing was associated with higher cost and, 375 in the end, turned out to be less cost-efficient.

\section{6. Conclusions}

377 In this study, a modeling approach of pasture BMP effectiveness was developed based on HRU-based 378 representation of individual pasture subareas including stream, riparian zone, and various slope grazing 379 lands. Based on the HRU distribution in the SWAT model built for Pottawatomie Creek Watershed in 380 eastern Kansas, four scenarios with combinations of off-stream watering site and stream fencing BMPs 381 were evaluated in synthetic pasture and a whole watershed.

382 The presence of the off-stream watering site reduced the time cattle spent in the flood plain area as 383 well as the overall pollutant load in the stream. This resulted in the cumulative effectiveness index being 384 above $20 \%$ for all BMP scenarios, with an additional gain of $2 \%$ if the stream was fenced. Sediment 385 contribution from stream bank erosion was not accounted in the methodology due to limitations of the 386 SWAT model, but can be incorporated in the approach if an amount of bank soil loss is known for various 387 stocking rates. The methodology was applied to evaluate BMP proposals in a BMP auction conducted in 388 an eastern Kansas watershed. 


\section{Acknowledgements}

390 The authors thank Mr. Josh Roe (watershed economist), Mr. Herschel George (watershed specialist), 391 and Dr. Verel Benson (Benson Consulting) for multiple discussions leading to development of livestock 392 BMP ranking methodology. reviewers for valuable comments that led to the improvement of the 393 manuscript.

\section{References}

395 Agouridis, C.T., Edwards, D.R., Workman, S.R., Bicudo, J.R., Koostra, B.K., Vanzant, E.S., Taraba, J.L., 396 2005. Streambank erosion associated with grazing practices in the humid region. Trans. ASABE 397 48(1): 181-190.

398 APHA, 1998. Standard Methods for the Examination of Water and Wastewater. 20th ed. Clesceri, L.S., Greenberg, A.E., Eaton, A.D. (Eds.). Washington, D.C.: American Public Health Association.

Arnold, J. G., Srinivasan, R., Muttiah, R.S., Williams, J.R., 1998. Large Area Hydrologic Model Development and Assessment Part 1: Model Development. J. Am. Water Resour. As. 34(1): 73-89.

Atkinson, S., Tietenberg, T., 1991. Market failure in incentive-based regulation: The case of emissions trading. J. Environ. Econ. Manag. 21(1): 17-31.

ASAE Standards, 1999. $45^{\text {th }}$ Edition. St. Joseph, Mich.: American Society of Agricultural Engineers.

Clawson, J.E., 1993. The use of off-stream water developments and various water gap configurations to modify the watering behavior of grazing cattle. M.S. Thesis, Corvallis, Oregon: Oregon State University.

Douglas-Mankin, K.R., Srinivasan, R., Arnold, J.G., 2010. Soil and Water Assessment Tool (SWAT) model: Current developments and applications. Trans. ASABE 53(5): 1423-1431.

ESRI, 2011. ArcMap 10. Environmental Systems Resource Institute. Redlands, California. 
Gassman, P.W., Reyes, M.R., Green, C.H., Arnold J.G., 2007. The Soil and Water Assessment Tool: Historical development, applications, and future research directions. Trans. ASABE 50(4): 12111250.

Haan, M.M., Russell, J.R., Powers, W.J., Kovar, J.L., Benning, J.L., 2006. Grazing Management Effects on Sediment and Phosphorus in Surface Runoff. Rangeland Ecol. Manag. 59: 607-615.

Homer, C., Dewitz, J., Fry, J., Coan, M., Hossain, N., Larson, C., Herold, N., McKerrow, A., VanDriel, J.N., Wickham, J. 2007. Completion of the 2001 National Land Cover Database for the Conterminous United States. Photogrammetric Engineering and Remote Sensing. 73(4): 337-341.

Lemunyon, J. L., R.G., Gilbert (1993). The concept and need for a phosphorus assessment tool. J. Prod. Agric. 6(4): 483-486.

Line, D.E., Harman, W.A., Jennings, G.D., Thompson, E.J., Osmond, D.L., 2000. Nonpoint-source pollutant load reductions associated with livestock exclusion. J. Environ. Qual. 29(6): 1882-1890.

423 Mankin, K.R., Hutchinson, S.L., Harner, J.P., Clark, P.A., Barnes, P.L., 2007. Performance evaluation of 424 wetlands in Northeast Kansas - Final report. KDHE Contract No. 2001-0001 (Part 4). Topeka, $425 \quad$ Kansas: Kansas Dept. of Health and Environment, Bureau of Water.

426 McInnis, M.L., McIver, J., 2001. Influence of Off-Stream Supplements on Streambanks of Riparian 427 Pastures. J. Range Manage 54(6): 648-652.

428 Miner, J.R., John C.B., Moore, J.A., 1992. Will a Water Trough Reduce the Amount of Time Hay-Fed Livestock Spend in the Stream (And Therefore Improve Water Quality)? Rangelands 14(1): 35-38.

430 Moriasi, D.N., Arnold, J.G., Van Liew, M.W., Bingner, R.L., Harmel, R.D., Veith, T.L., 2007. Model 431 evaluation guidelines for systematic quantification of accuracy in watershed simulations. Trans. $432 \quad$ ASABE 50(3): 885-900. 
Nash, J.E., Sutcliffe, J.V., 1970. River flow forecasting through conceptual models: Part I. A discussion of principles. J. Hydrol. 10(3): 282-290.

NCDC, 2009. Climate-Radar Data Inventories. Asheville, NC: National Climatic Data Center. Available at: http://www.ncdc.noaa.gov/oa/ncdc.html. Accessed in November 2010.

Neitsch, S.L., Arnold, J.G., Kiniry, J.R., Williams, J.R., 2005. Soil and Water Assessment Tool Theoretical Documentation version 2005. Temple, Texas: Grassland, Soil and Water Research Laboratory, USDA-ARS \& Blackland Research and Extension Center, Texas A\&M University.

Neitsch, S.L., Arnold, J.G., Kiniry, J.R., Srinivasan, R., Williams, J.R., 2004. Soil and Water Assessment Tool Input / Output File Documentation version 2005. Temple, Texas: Grassland, Soil and Water Research Laboratory, USDA-ARS.

Nelson, N.O., Shober, A.L. 2012. Evaluation of phosphorus indices after twenty years of science and development. J. Environ. Qual. 41(6): 1703-1710.

Ohlenbusch, P.D., Harner, J.P., III, 2003. Grazing distribution. MF-515. Kansas State University. Agricultural Experiment Station and Cooperative Extension Service. Manhattan, KS.

Ohlenbusch, P.D., Watson, S.D., 1994. Stocking rate and grazing management. MF-1118. Manhattan, Kansas: Kansas State University, Agricultural Experiment Station and Cooperative Extension Service.

Ouyang, W., Skidmore, A.K., Hao, F., Wang T., 2010. Soil erosion dynamics response to landscape pattern. Sci. Total Environ. 408: 1358-1366.

Owens, L.B., Edwards, W.M., Van Keuren, R.W., 1996. Sediment losses from a pastured watershed before and after stream fencing. J. Soil Water Conserv. 51(1): 90-94.

Pandey, V., Kiker, G.A., Campbell, K.L., Williams, M.J., Coleman, S.W., 2009. GPS monitoring of cattle location near water features in south Florida. Appl. Eng. Agric. 25(4): 551-562. 
Penn, C.J., Bryant, R.B., Needelman, B., Kleinman, P., 2009. Spatial Distribution of Soil Phosphorus Across Selected New York Dairy Farm Pastures and Hay Fields. Soil Sci 172(10): 797-810.

Redfearn, D.D., Bidwell T.G., 1997. Stocking Rate: The Key to Successful Livestock Production. Fact Sheet F-2871. Stillwater, Oklahoma: Oklahoma Cooperative Extension Service.

Richards, C.E., Munster, Vietor, D.M., Arnold, J.G., White, R., 2008. Assessment of a turfgrass sod best management practice on water quality in a suburban watershed. J. Environ. Manage. 86: 229-245.

462 Santhi, C., Arnold, J.G., Williams, J.R., Dugas, W.A., Srinivasan, R., Hauck, L.M., 2001. Validation of 463 the SWAT model on a large river basin with a point and nonpoint sources. J. American Water Resour. Assoc. 37(5): 1169-1188.

Sauer, T.J., Meek, D.W., 2003. Spatial variation of plant-available phosphorus in pastures with contrasting management. Soil Sci. Soc. Am. J. 67(3): 826-836.

Sheffield, R.E, Mostaghimi, S., Vaughan, D.H., Collins, E.R. Jr., Allen, V.G., 1997. Off-stream water sources for grazing cattle as a stream bank stabilization and water quality BMP. Trans. ASABE 40(3). 595-604.

Sheshukov, A.Y., Daggupati, P., Douglas-Mankin, K. R., Lee, M.-C. 2011. High Spatial Resolution Soil Data for Watershed Modeling: 1. Development of a SSURGO-ArcSWAT Utility. J. Natural \& Environ. Sci. 2(2). 15-24.

Smith, C.M., Nejadhashemi, A.P., Leatherman, J.C., 2009. Using a BMP Auction as a Tool for the Implementation of Conservation Practices. J. Extension 47(4).

Smith, C.M., Peterson, J.M., Leatherman, J.C., 2007. Attitudes of Great Plains producers about best management practices, conservation programs, and water quality. J. Soil Water Conserv. 62(5): 97A-103A. 
Stavins, R.N., 1998. What Can We Learn from the Grand Policy Experiment? Lessons from $\mathrm{SO}_{2}$ Allowance Trading. J. Econ. Perspect. 12(3): 69-88.

USDA-NASS, 2008. Kansas agricultural statistics: Kansas county data. Washington, D.C.: USDA National Agric. Statistics Service. Available at: http://www.nass.usda.gov/QuickStats/Create_County_Indv.jsp. Accessed in January 2009.

USDA-NRCS, 1994. The Phosphorus Index a Phosphorous Assessment Tool. United States Department of Agriculture, Natural Resources Conservation Service. Available at http://www.nrcs.usda.gov/techni cal/ecs/nutrient/pindex.html. Accessed in November 2010.

U.S. EPA, 2009. Marais des Cygnes Basin, KS and MO, Targeted Watersheds Grant Program, U.S. Environmental Pollution Agency. Available at: http://www.epa.gov/twg. Accessed in January 2011.

USGS, 2009. Daily streamflow for the nation. Washington, D.C.: U.S. Geological Service. Available at: http://nwis.waterdata.usgs.gov/nwis. Accessed November 2010.

Wade, T.G., Schultz, B.W., Wickham, J.D., Bradford, D.F., 1998. Modeling the potential spatial distribution of beef cattle grazing using a Geographic Information System. J. Arid Environ. 38(2): $325-334$.

White, M.J., Storm, D.E., Smolen, M.D., Zhang H., 2009. Development of a quantitative pasture phosphorous management tool using the SWAT model. J. Am. Water Resour. As. 45(2): 397-406. 


\section{Figure Captions:}

502 Fig. 1. Study watershed, showing (a) Pottawatomie Creek Watershed in east-central Kansas; (b) stream network, delineated subwatersheds, grazing area in 260-hectare land parcels, weather stations, and USGS gauging station used in streamflow calibration; and (c) aerial image of the Nichols dairy pasture used in sediment and nutrient calibration.

Fig. 2. (a) Annual average loads of total suspended solids (TSS), organic P (ORGP), sediment-attached $\mathrm{P}(\mathrm{SEDP})$, soluble $\mathrm{P}(\mathrm{SOLP})$, organic $\mathrm{N}(\mathrm{ORGN})$, and nitrates $(\mathrm{NO}-\mathrm{N})$ for baseline scenario of the 508 synthetic pasture, and (b) load changes from the baseline for four BMP scenarios. Subareas G1, G2, R, S 509 were set as default at 50 ha, 11 ha, 3 ha, and 1 ha, respectively, while range bars in (a) represent grazing 510 subarea G1 varying from 0 to 61 ha.

511 Fig. 3. Pasture BMP cumulative effectiveness index (CEI, \%) for four BMP scenarios as a function of 512 the percentage of subarea G1 in total grazing area.

513 Fig. 4. BMP cumulative effectiveness index (CEI, \%) for W1N scenario in Pottawatomie Creek 514 watershed and synthetic pasture. The CEI is calculated for various daily stream grazing times as a 515 function of stream time reduction (based on increasing use of an alternative watering site). The shaded 516 area and dashed line illustrate range and a mean of CEI for 403 pastures in Pottawatomie Creek 517 watershed, while solid lines show CEI for synthetic pasture. 
3

4

5

6

8

12 13 14

\section{Table Captions:}

520 Table 1. SWAT management operation input parameters and their values within a grazing land (G1, 521 G2) HRU and a riparian buffer (R) HRU (VAR means variable values).

522 Table 2. SWAT parameters adjusted during calibration runs in Pottawatomie Creek watershed.

523 Table 3. Observed streamflow, pollutant concentrations, and statistics for default and final calibration 524 runs in Pottawatomie Creek watershed ( $\mathrm{n}$ is the number of samples). 


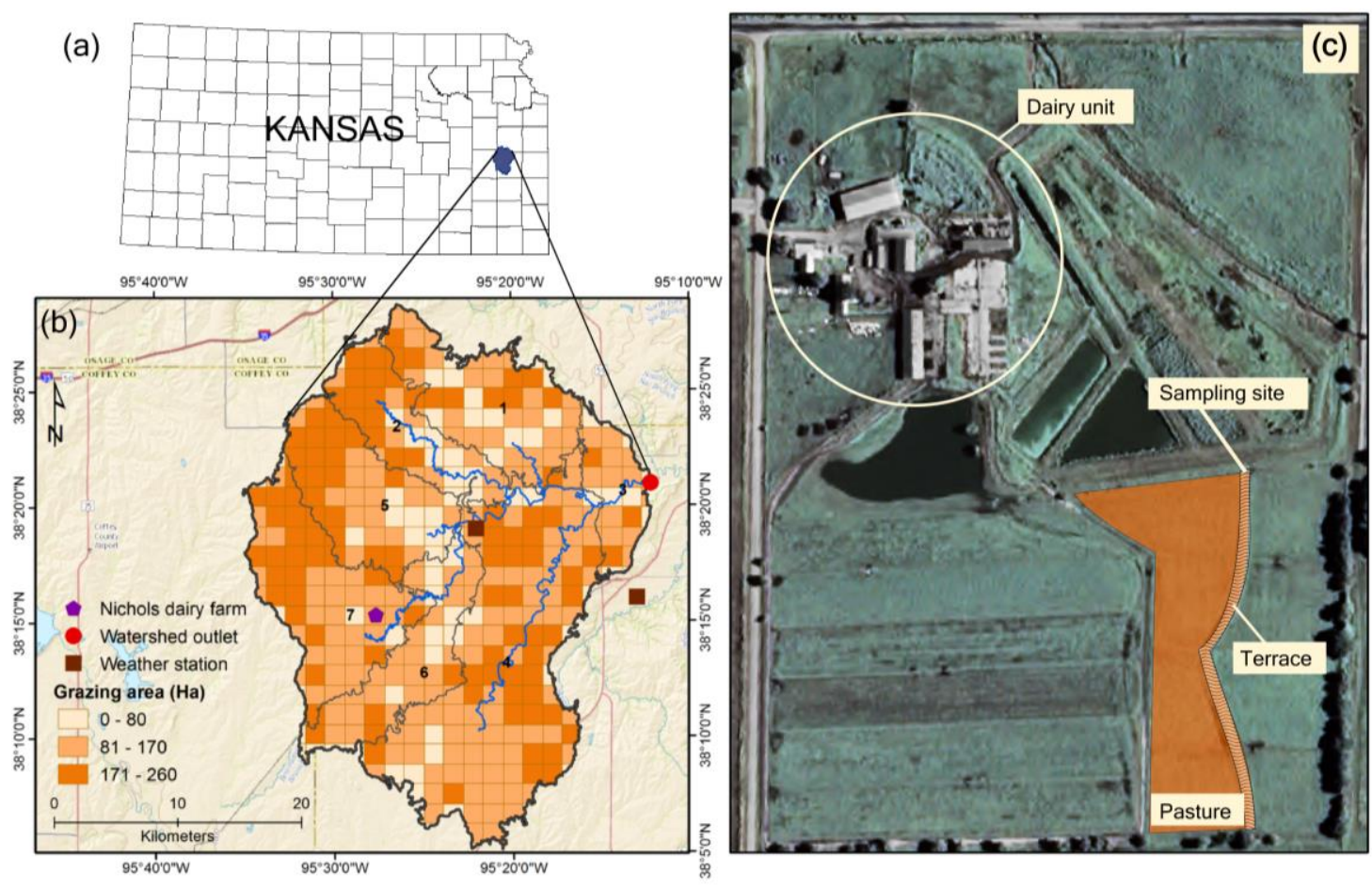

Fig. 1 Study watershed, showing (a) Pottawatomie Creek Watershed in east-central Kansas; (b) stream network, delineated subwatersheds, grazing area in 260-hectare land parcels, weather stations, and USGS gauging station used in streamflow calibration; and (c) aerial image of the Nichols dairy pasture used in sediment and nutrient calibration. 

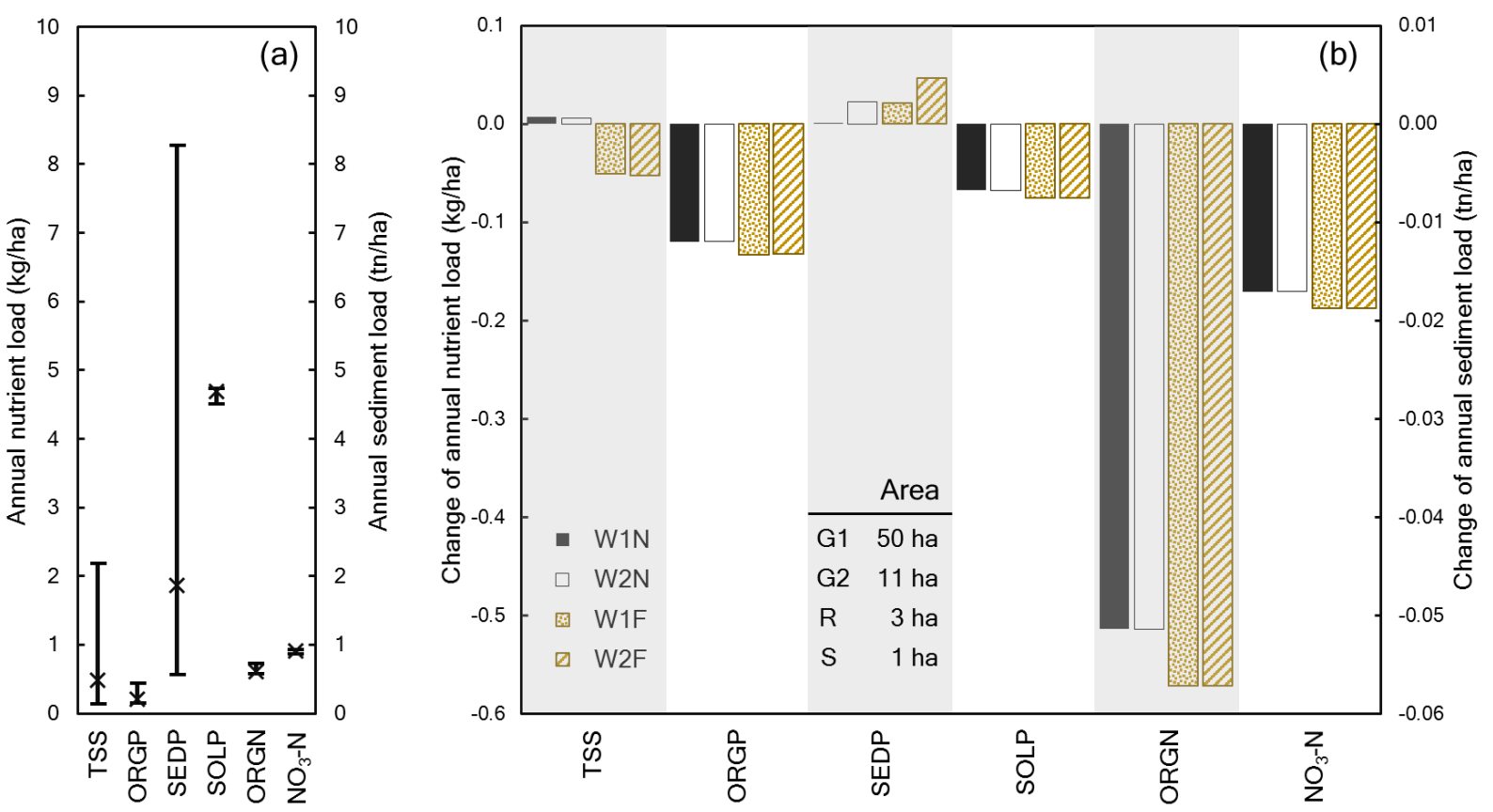

Fig. 2 (a) Annual average loads of total suspended solids (TSS), organic P (ORGP), sediment-attached P (SEDP), soluble $\mathrm{P}(\mathrm{SOLP})$, organic $\mathrm{N}(\mathrm{ORGN})$, and nitrates $\left(\mathrm{NO}_{3}-\mathrm{N}\right)$ for baseline scenario of the synthetic pasture, and (b) load changes from the baseline for four BMP scenarios. Subareas G1, G2, R, S were set as default at 50 ha, 11 ha, 3 ha, and 1 ha, respectively, while range bars in (a) represent grazing subarea G1 varying from 0 to 61 ha. 


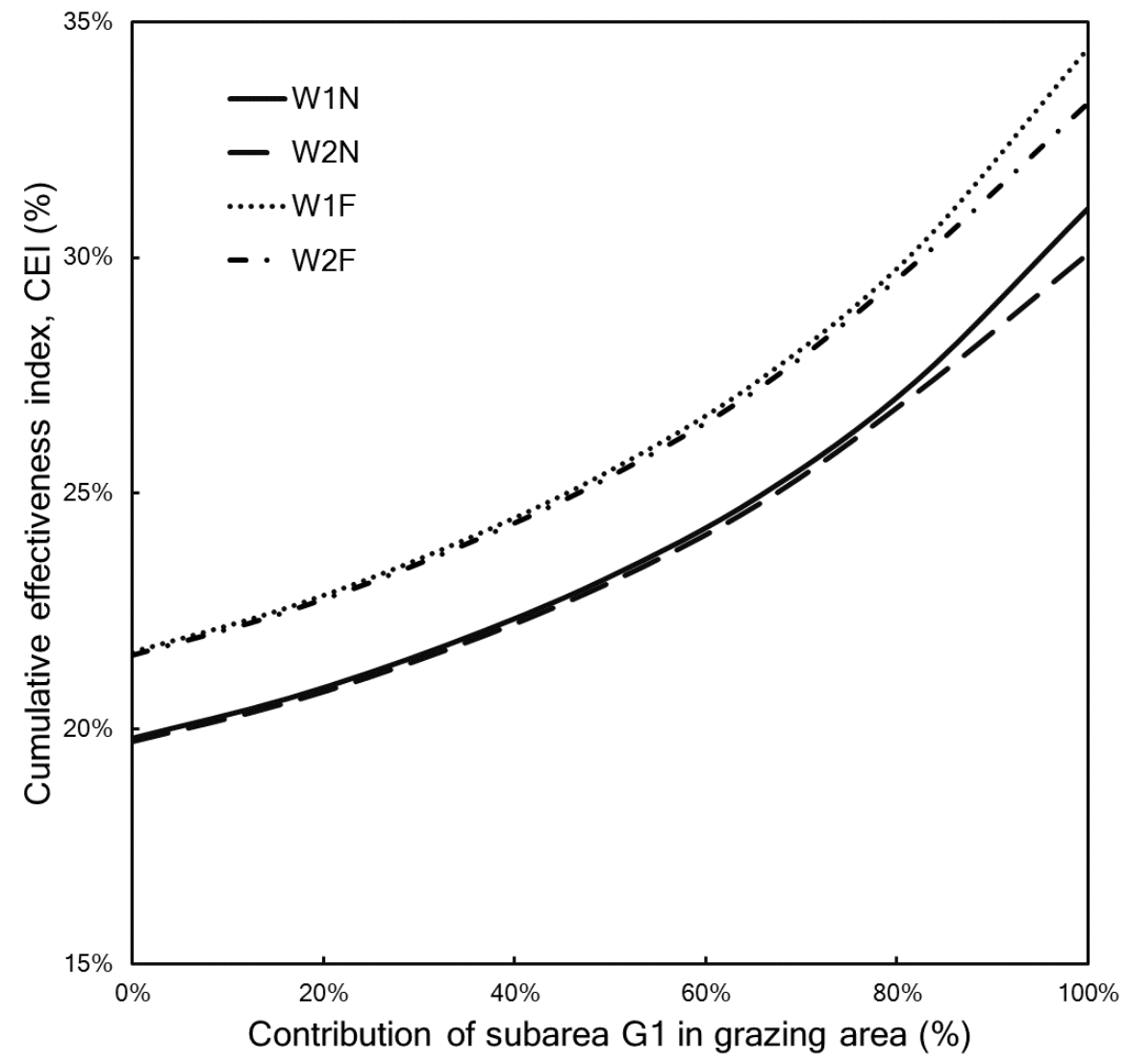

Fig. 3 Pasture BMP cumulative effectiveness index (CEI, \%) for four BMP scenarios as a function of the percentage of subarea G1 in total grazing area. 


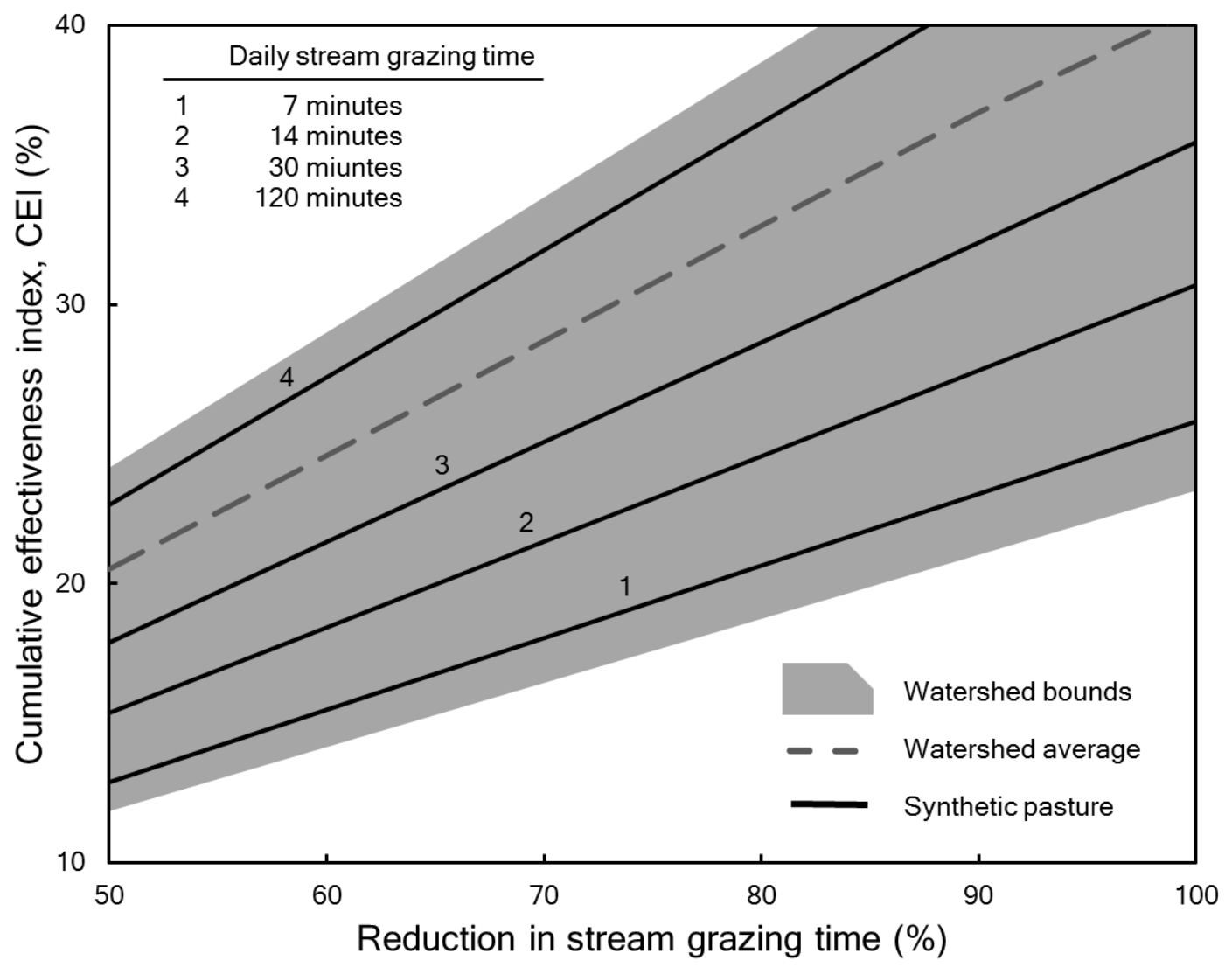

Fig. 4 BMP cumulative effectiveness index (CEI, \%) for W1N scenario in Pottawatomie Creek watershed and synthetic pasture. The CEI is calculated for various daily stream grazing times as a function of stream time reduction (based on increasing use of an alternative watering site). The shaded area and dashed line illustrate range and a mean of CEI for 403 pastures in Pottawatomie Creek watershed, while solid lines show CEI for synthetic pasture. 
Table 1 SWAT management operation input parameters and their values within a grazing land (G1, G2) HRU and a riparian buffer (R) HRU (VAR means variable values).

557

\begin{tabular}{|l|l|c|c|c|}
\hline Description & SWAT parameter & HRU & Value & Units \\
\hline Grass type & PLANT_ID & G1,G2 & 38 & - \\
\hline Management operation & MGT_OP & G1,G2,R & 9 & - \\
\hline Type of animals & MANURE_ID & G1,G2,R & 9 & - \\
\hline Daily manure & MANURE_KG & G1,G2,R & VAR & $\mathrm{kg} / \mathrm{ha}$ \\
\hline Start of grazing & YEAR,MONTH,DAY & G1,G2,R & VAR & - \\
\hline Number of grazing days & GRZ_DAYS & G1,G2,R & 280 & Days \\
\hline Type of fertilizer & FRT_ID & G1,G2 & 23 & - \\
\hline Amount of fertilizer & FRT_KG & G1,G2 & 6.8 & $\mathrm{Kg}$ \\
\hline Biomass consumed daily & BIO_EAT & G1,G2,R & VAR & $\mathrm{kg} / \mathrm{ha}$ \\
\hline Biomass trampled daily & BIO_TRMP & G1,G2,R & VAR & $\mathrm{kg} / \mathrm{ha}$ \\
\hline Minimum dry biomass & BIOMIN & G1,G2 & 500 & $\mathrm{~kg} / \mathrm{ha}$ \\
\hline Initial pasture and buffer conditions & CN2 & G1,G2,R & VAR & - \\
\hline
\end{tabular}


Table 2 SWAT parameters adjusted during calibration runs in Pottawatomie Creek watershed.

\begin{tabular}{|l|c|c|c|c|}
\hline $\begin{array}{l}\text { SWAT } \\
\text { parameter }\end{array}$ & $\begin{array}{c}\text { Default } \\
\text { value }\end{array}$ & $\begin{array}{c}\text { Range } \\
\text { tested }\end{array}$ & $\begin{array}{c}\text { Calibrated } \\
\text { value }\end{array}$ & Description \\
\hline
\end{tabular}

Streamflow at watershed outlet

\begin{tabular}{|l|c|c|c|c|}
\hline CN2 & Varies & 67 to 100 & $-5 \%$ & SCS curve number, antecedent moisture condition 2
\end{tabular}

\begin{tabular}{l|c|c|c|l}
\hline ESCO & 0.95 & 0 to 1 & 0.8 & Soil evaporation compensation factor \\
\hline
\end{tabular}

\begin{tabular}{l|c|c|c|l|}
\hline SURLAG & 4 & 1 to 12 & 1 & Surface runoff lag coefficient \\
\hline
\end{tabular}

\begin{tabular}{l|c|c|c|c}
\hline CANMX & 0 & -- & Forest: $4.2^{*}$ & Maximum canopy storage $\left(\mathrm{mm} \mathrm{H}_{2} \mathrm{O}\right)$
\end{tabular}

\begin{tabular}{l|c|c|c|c} 
& 0 & -- & $\begin{array}{c}\text { Crops: } 2.2^{*} \\
\text { Grass: } 3.5^{*}\end{array}$ & \\
\hline RCHRGDP & 0.05 & 0 to 1 & 1 & Dee \\
\hline SFTMP & 1 & -5 to 5 & -1 & S \\
\hline SMTMP & 1 & -5 to 5 & 4 & S
\end{tabular}

Deep aquifer percolation factor

Pollutant concentrations at pasture edge

\begin{tabular}{|l|l|c|c|l|}
\hline SOL_ORGN & 0 & 850 to 8000 & $5000^{* *}$ & Initial organic N concentration in soil layer (ppm) \\
\hline SOL_ORGP & 0 & 150 to 5000 & $4000^{* * *}$ & Initial organic P concentration in soil layer (ppm) \\
\hline SOL_SOLP & 0 & 250 to 1000 & 750 & Initial soluble P concentration in soil layer (ppm) \\
\hline BIOMIX & 0 & 0 to 1 & 0.8 & Biological mixing efficiency \\
\hline BIOMIN & 0 & 0 to 650 & 500 & Minimum plant biomass for grazing (kg/ha) \\
\hline
\end{tabular}

*Ouyang et al. (2010); ** Santhi et al. (2001); *** Richards et al. (2008) 
Table 3 Observed streamflow, pollutant concentrations, and statistics for default and final calibration runs in Pottawatomie Creek watershed ( $\mathrm{n}$ is the number of samples).

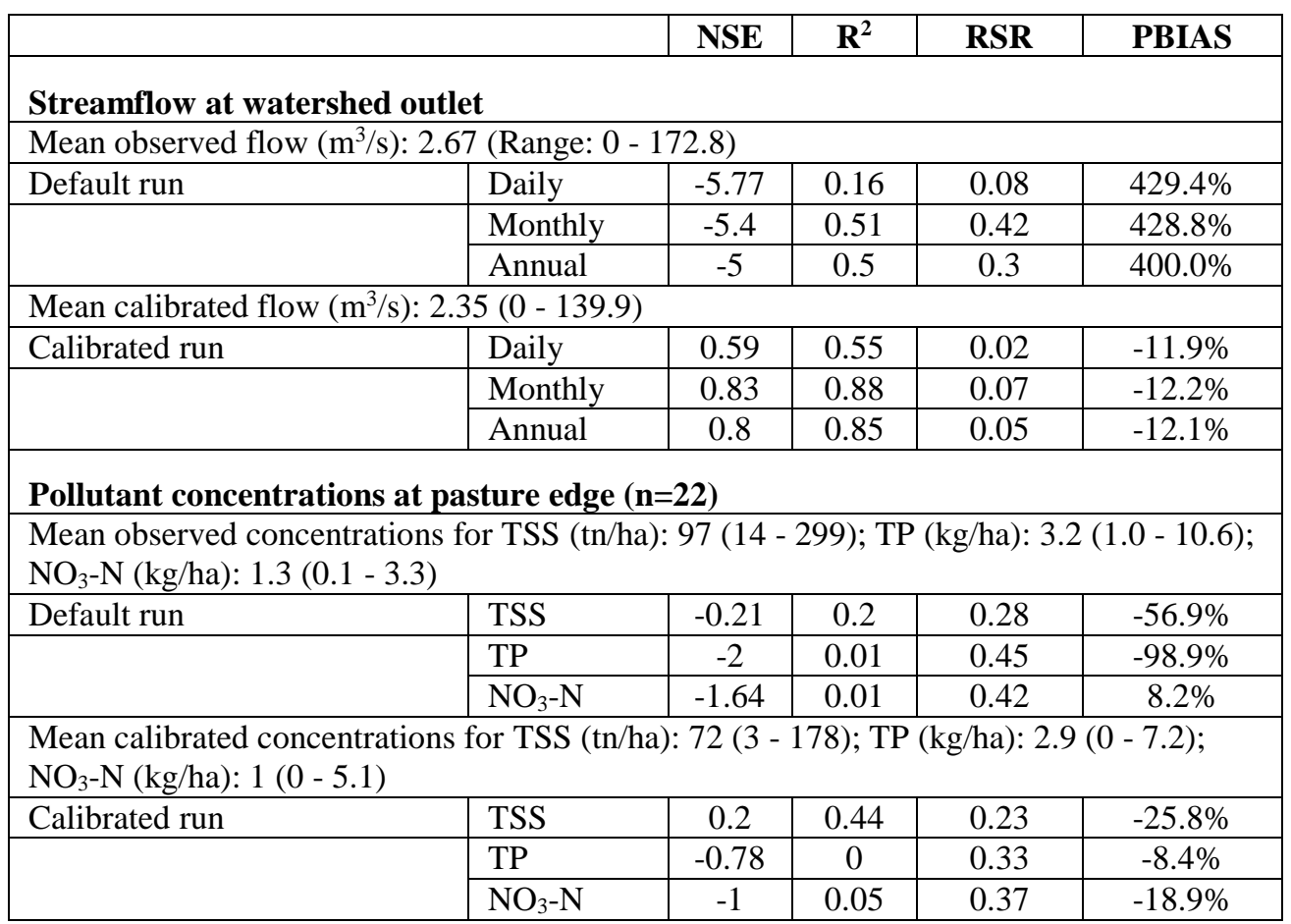

